\title{
Konstruksi Alat Ukur Konservatisme Islam di Indonesia
}

\section{Constructing the Islamic Conservatism Scale in Indonesian Context}

\author{
Nesya Adira, Intan Permatasari, Selfiyani Lestari, Boma Baswara, Nudzran Yusya, \\ Ali Nina Liche Seniati \\ Fakultas Psikologi Universitas Indonesia, Depok, Indonesia
}

\begin{abstract}
Islamic conservatism has been said to inspire the rise of intolerance between religions in Indonesia and the growth of radical ideologies which threatens government stability. To understand the rise of Islamic conservatism, two studies were conducted to construct a valid and reliable psychological measurement which is able to measure the level of Islamic conservatism among Indonesian people. This Islamic conservatism scale consists of 5 dimensions with 2-3 indicators for each dimension. The validity testing was conducted using Confirmatory Factor Analysis, while the reliability testing of the instrument was conducted using Cronbach Alpha as internal consistency technique. The testings were conducted twice, in which the first one showed that 5 dimensions-scale is unfit, although reliable. When 2 dimensions with high social desirable items were excluded, the scale with 3 dimensions show a good fit, therefore the scale is valid and also reliable. Second study was conducted to measure convergent validity by correlating the 3-dimension scale with RWA scale. Result shows the scale has a significant positive correlation with RWA indicating the scale has a convergent validity.
\end{abstract}

Keywords: Conservatism, Islam, scale construction, Indonesia

\begin{abstract}
Abstrak: Konservatisme dalam agama Islam di Indonesia telah disebut melatarbelakangi terjadinya kasus-kasus intoleransi antar umat beragama yang mengancam stabilitas negara. Untuk mengukur pertumbuhan konservatisme Islam di Indonesia, dua studi dilakukan untuk mengkonstruksi alat ukur yang valid dan reliabel. Alat ukur yang ini memiliki lima dimensi dengan dua sampai tiga indikator per dimensi. Validitas konstruk alat ukur dilakukan dengan metode Confirmatory Factor Analysis dan reliabilitasnya diuji dengan Cronbach Alpha. Uji validitas dan reliabilitas dilakukan dua kali. Pengujian pertama pada alat ukur dengan 5 dimensi menunjukkan model tidak fit, namun reliabel. Pengujian kedua dilakukan pada alat ukur yang menghilangkan 2 dimensi yang memiliki tingkat social desirability tinggi. Hasilnya pengujian menunjukkan bahwa model alat ukur dengan 3 dimensi fit, yang berarti alat ukur valid. Selain itu alat ukur dengan 3 dimensi bersifat reliabel. Studi kedua dilakukan untuk mengukur validitas konvergen dengan mengkorelasikan alat ukur 3 dimensi dengan skala RWA. Hasil menunjukkan skala ini memiliki korelasi positif yang signifikan dengan RWA, mengindikasikan skala ini memiliki validitas konvergen.
\end{abstract}

Kata kunci: Konservatisme, Islam, konstruksi skala, Indonesia

Korespondensi tentang artikel ini dapat dialamatkan kepada Ali Nina Liche Seniati melalui e-mail: licheseniati@gmail.com 
Konservatisme Islam di Indonesia menunjukkan tren peningkatan setelah masa reformasi (van Bruinessen, 2011; 2014). Peningkatan konservatisme Islam di Indonesia ini ditandai oleh beberapa gejala seperti sikap intoleransi umat beragama, kekerasan dan diskriminasi yang dilakukan atas nama agama, hingga terorisme yang berbasis agama di Indonesia (Assyaukanie, 2018). Salah satu contoh fenomena terkait konservatisme Islam di Indonesia adalah gerakan populisme yang sering dikaitkan dengan pemilihan Gubernur dan Wakil Gubernur DKI Jakarta yang diwarnai dengan konflik politik identitas (Mietzner \& Muhtadi, 2018).

Assyaukanie (2017) melihat konflik politik saat itu sebagai puncak dari konservatisme Islam yang telah muncul sejak 15 tahun belakangan. Gerakan tersebut, yang umum dikenal sebagai Gerakan 212, bertajuk membela Islam, serta menyuarakan bahwa seorang muslim tidak boleh memilih pemimpin yang tidak beragama Islam (Setijadi, 2017). Gerakan Islam yang dipandang konservatif ini tidak hanya muncul pada saat pemilu Gubernur DKI Jakarta namun juga terjadi pada pemilihan umum (pemilu) presiden pada tahun 2019 (Arifianto, 2019; Mietzner \& Muhtadi, 2018, 2019). Pemilu tersebut telah memecah belah pendukung kedua calon presiden berdasarkan dimensi ideologis terkait bagaimana peran Islam dalam mengatur masalah pemerintahan (Fossati, 2019).

Tidak hanya dalam kontestasi politik, imbas dari gerakan konservatisme Islam juga merembet ke dalam kehidupan bermasyarakat. Peningkatan konservatisme diikuti juga dengan meningkatnya intoleransi beragama terhadap minoritas mulai dari sekte Islam non-mainstream seperti Ahmadiyah dan Syiah hingga Kristen, dan agama minoritas lainnya (Sebastian \& Arifianto, 2020). Intoleransi yang menjadi berita misalnya penolakan izin untuk pembangunan gereja dan pura di Jawa Barat, dan adanya larangan perayaan hari Natal di Sumatera Barat (BBCNews, 2019). Lem- baga swadaya masyarakat, SETARA, telah mendokumentasikan terjadinya peningkatan jumlah pelanggaran kebebasan beragama di Indonesia, mulai dari 134 pada tahun 2014, 196 di tahun 2015 dan 208 pada tahun 2016 (Lestari, 2017).

Dari berbagai fenomena yang telah disebutkan, kepentingan untuk memahami pertumbuhan konservatisme Islam semakin mendesak. Oleh karena itu, diperlukan suatu alat ukur psikologis yang dapat digunakan untuk membaca tingkat konservatisme yang ada saat ini di Indonesia yang dipengaruhi oleh pertumbuhan gerakan Islam konservatif.

Pembuatan alat ukur ini akan bermanfaat bagi beberapa pihak. Pertama, peneliti, khususnya peneliti yang hendak meneliti mengenai topik yang berkaitan dengan konservatisme Islam sehingga dapat membuat penelitian dengan memanfaatkan alat ukur ini. Kedua, pengukuran konstruk konservatisme Islam dapat membantu pemerintah maupun institusi terkait dalam membaca tumbuhnya paham-paham radikal yang dipandang dapat mengancam stabilitas negara. Hamayotsu (2018) berargumen bahwa gabungan pandangan Islam konservatif dengan paham-paham agama radikal yang menolak untuk menerima pandangan lain adalah akar dari munculnya kasus-kasus intoleransi terhadap minoritas di negara-negara Asia Tenggara seperti Indonesia dan Malaysia. Dengan adanya alat ukur yang valid dan reliabel, maka dapat memudahkan riset-riset selanjutnya terkait pertumbuhan gerakan konservatisme Islam di Indonesia.

Konservatisme Islam adalah salah satu bentuk konservatisme religius. Dalam alat ukur yang dikembangkan ini, definisi konservatisme Islam merujuk pada definisi konservatisme religius sebagai sikap yang menolak interpretasi modern, liberal, dan progresif dari ajaran agama, serta mempromosikan kepatuhan mutlak dan intoleransi terhadap ajaran agama lain selain agama Islam (Terrizzi, Shook, \& Larry Ventis, 2012; Van Bruinessen, 2011). 
Alat ukur konservatisme religius sebelumnya telah banyak dikembangkan di Barat, namun hanya terbatas pada pandangan agama secara umum atau spesifik merujuk agama Katolik dan Kristen saja (Odahl-Ruan, Todd, \& Wilson, 2017; Weima, 1965). Skala ini tentu saja tidak cocok apabila digunakan untuk mengukur konservatisme religius yang spesifik dalam agama Islam, karena setiap agama memiliki ciri khas tersendiri (Weima, 1965).

Pengukuran terhadap konservatisme Islam dalam konteks masyarakat Indonesia pernah dilakukan oleh Mietzner dan Muhtadi (2018). Pengukuran tersebut dilakukan untuk menganalisa perkembangan konservatisme Islam dalam masyarakat Indonesia dengan cara melakukan analisis terhadap data yang dikumpulkan Lembaga Survei Indonesia (LSI), Indikator Politik Indonesia, dan Saiful Mujani Research and Consulting (SMRC). Data tersebut dikumpulkan dari kuesioner yang berisi pertanyaan-pertanyaan dengan kategori jawaban yaltidak, dengan contoh seperti: apakah masyarakat mengizinkan perayaan hari suci agama lain, pembangunan tempat ibadah agama lain, dan apakah mereka memberi donasi terhadap usaha implementasi hukum Islam. Penelitian tersebut memiliki keterbatasan karena bentuk respon jawaban ya/tidak akan cenderung memaksa responden yang tidak memiliki jawaban dikotomis tersebut untuk tetap menjawab ya/tidak. Hal ini menyebabkan responden tidak bisa mengekspresikan jawaban yang sebenarnya (Schuman \& Presser, 1981). Selain itu, pertanyaan-pertanyaan tersebut merupakan bagian dari pengukuran tingkat intoleransi beragama di Indonesia, dan tidak spesifik mengukur dasar pandangan konservatisme dalam Islam itu sendiri.

Sampai saat ini, belum didapati adanya skala yang dibuat untuk mengukur kecenderungan konservatisme khusus pada penganut Islam dalam konteks Indonesia. Berdasarkan alasan tersebut, perlu dilakukan penelitian untuk menyusun skala pengukuran konservatisme Islam yang sesuai dengan konteks masyarakat Indonesia. Penelitian ini dilakukan untuk membuat sebuah alat ukur yang valid dan reliabel untuk mengukur konstruk konservatisme Islam yang sesuai dengan keadaan masyarakat muslim di Indonesia.

\section{Metode}

Proses pengembangan alat ukur dilakukan dalam 2 studi. Pada studi 1, kami melakukan penyusunan alat ukur dan melakukan pengukuran psikometrik dasar dengan menganalisis statistik deskriptif masing-masing aitem dan skala untuk menyeleksi aitem-aitem baik. Selanjutnya pada studi 2, kami melakukan pengambilan data dengan alat ukur yang dikembangkan dalam studi 1 serta melakukan uji validitas CFA dan validitas konvergen.

\section{Studi 1}

\section{Sampel dan Teknik Pengambilan Sampel}

Pengisian kuesioner dilakukan secara daring pada Google Forms dan responden yang dijadikan sampel harus memenuhi kriteria WNI berusia di atas 21 tahun dan beragama Islam. Pertimbangan pemilihan usia karena pada usia 21 tahun, individu telah memasuki masa dewasa awal. Pada masa dewasa awal, individu telah melewati tahap pembentukan identitas dan ideologinya mengenai dunia, sikap politik maupun agama juga akan terbentuk. Agama Islam dimasukkan dalam kriteria sampel karena alat ukur ini mengukur mengenai konservatisme spesifik dalam agam Islam.

Pengambilan sampel penelitian dilakukan dengan teknik snowball sampling karena tautan kuesioner disebarkan secara daring (dalam jaringan/online) melalui media sosial kepada jaringan yang dimiliki penulis, dan meminta bantuan para kenalan untuk selanjutnya menyebarkannya pada jaringan yang dimiliki masing-masing.

Dari kuesioner yang disebarkan secara daring, diperoleh 257 orang responden 
yang mengisi kuesioner dan dimasukkan dalam analisis. Sebanyak 68,1\% atau 175 partisipan berjenis kelamin perempuan, dan sisanya adalah laki-laki. Kebanyakan partisipan tersebar di pulau Jawa dengan 39,7\% atau 107 partisipan berdomisili di Jawa Barat. Berdasarkan pendidikan terakhir, kebanyakan partisipan memiliki pendidikan terakhir S1, yaitu 63,42\% atau 163 orang; sisanya adalah SMA $(25,68 \%)$, S2 $(7 \%)$, dan diploma $(3,88 \%)$. Rata-rata usia partisipan adalah 24,18 tahun, dengan responden termuda berusia 22 tahun dan tertua berusia 55 tahun.

Pada tampilan pertama kuesioner, partisipan diberikan informed consent untuk menunjukkan kesediaannya berpar-tisipasi dalam penelitian. Pada halaman selanjutnya, partisipan diminta untuk mengisi data demografis seperti nama atau inisial, usia, asal daerah dan agama. Setelahnya, responden mengisi kuesioner Konservatisme Islam yang telah disusun sebelumnya. Responden diberi kesempatan untuk mengikuti undian pemberian hadiah berupa saldo uang elektronik Rp. 15.000,00 jika berkenan mencantumkan nomor ponsel yang kerahasiaannya dijaga oleh peneliti. Hanya para responden yang menyetujui informed consent yang dapat melanjutkan pengisian kuesioner. Selain itu, hanya responden yang melengkapi semua data dan respon seluruh aitem kuesioner yang dimasukkan ke dalam sampel akhir yang akan dianalisis.

\section{Penyusunan Alat Ukur}

Penyusunan alat ukur dilakukan dalam beberapa tahapan. Tahap pertama adalah tahap modifikasi yang dimulai dengan memodifikasi dimensi dalam penelitian Zuhdi (2018) terkait konserva-tisme dalam Islam. Dimensi ini diperoleh dari hasil penelitian kualitatif Zuhdi yang melakukan wawancara seputar isu-isu yang merepresentasikan perdebatan antara Islam konservatif dan moderat. Kelima isu tersebut kemudian ditarik sebagai dimensi-dimensi dalam konservatisme Islam. Berbagai dimensi tersebut meliputi sikap terhadap pemerintahan, sikap terhadap Islam nonmainstream, sikap terhadap hubungan antara muslim dan bukan muslim (nonmuslim), sikap terhadap Islam dan media, serta pandangan terkait gender.

Tahap kedua adalah pengembangan alat ukur. Setelah dimensi terbentuk dan didefinisikan, maka tiap dimensi diturunkan menjadi indikator. Pembentukan indikator didasarkan pada deskripsi penjelasan tiap dimensi yang diberikan oleh Zuhdi (2018). Penjelasan tiap dimensi dijabarkan pada Tabel 1. Proses pengembangan alat ukur ini mulai dari perencanaan hingga pembentukan blueprint telah melewati proses content validity dari pengajar yang ahli metodologi dan pengajar yang ahli dalam bidang Psikologi Politik dari Universitas Indonesia.

Setelah terbentuk indikator, maka tiap indikator kemudian diturunkan men-jadi butir-butir pernyataan yang isinya mencerminkan indikator tersebut. Tiap dimensi memiliki 12 aitem kecuali dimensi sikap terhadap Islam non-mainstream yang memiliki 13 aitem. Secara keseluruhan tersusun 61 aitem. Alat ukur berbentuk Likert dengan 6 poin dimana pilihan jawaban berkisar dari 1 (sangat tidak setuju) hingga 6 (sangat setuju).

Sebelum didistribusikan, alat ukur sekali lagi melalui proses validasi dengan melakukan uji kelayakan aitem yang diberikan kepada ahli dan uji keterbacaan pada responden yang memiliki karakteristik yang sama dengan responden saat pengumpulan data. Ahli yang dipilih adalah seorang ilmuwan muslam yang mendalami ilmu tafsir agama dan antropologi. Hal ini dilakukan untuk memastikan aitem-aitem dalam alat ukur telah tepat dan layak menjelaskan isu-isu yang diangkat dalam agama Islam. Uji keterbacaan dilakukan dengan memberikan kuesioner pada 5 orang dan meminta mereka untuk memberi tanda apakah aitem telah cukup baik dan dapat dipahami atau belum. Jika terdapat aitem 
Tabel 1. Blueprint Alat Ukur Konservatisme Islam

\begin{tabular}{l} 
Dimensi \\
\hline 1. Sikap terhadap pemerintahan (gov) \\
Dukungan pada bentuk pemerintahan \\
berbasis agama \\
2. Hubungan dengan bukan muslim (hub) \\
Persepsi mengenai hubungan ideal yang \\
menyangkut hak dan kewajiban antara \\
pemeluk agama Islam dan agama lainnya \\
3. Islam non-mainstream (nmi) \\
Kepercayaan bahwa kelompok Islam non- \\
mainstream seperti Syi'ah dan Ahmadiyah \\
harus dilarang di Indonesia karena mereka \\
telah melanggar prinsip-prinsip dalam \\
Islam dan keberadaan mereka dapat \\
menjadi berbahaya bagi umat Islam \\
4. Islam dan media (med) \\
Penolakan pemuatan atau pelibatan \\
konten Islam dalam media, karena media \\
tidak merepresentasikan Islam dengan baik \\
5ermasalahan gender (gen) \\
Ketidaksetujuan keterlibatan dan hak-hak \\
perempuan dalam ruang publik
\end{tabular}

yang belum baik, peneliti langsung meminta mereka menjelaskan bagian mana yang belum dipahami dan memberikan solusi perbaikan. Uji ini khususnya dilakukan untuk memastikan aitem-aitem tidak multitafsir dan mengandung kalimat atau istilah yang dapat dipahami dengan baik oleh masyarakat awam. Berdasarkan hasil dari kedua pengujian tersebut, dilakukan revisi terhadap aitem. Hasil revisi ini yang kemudian disebarkan kepada responden.

\section{Reliabilitas dan Validitas Alat Ukur}

Reliabilitas masing-masing dimensi alat ukur diuji dengan teknik konsistensi internal yaitu Cronbach Alpha. Teknik ini dipilih karena pengadministrasian alat ukur dilakukan hanya sekali. Pengujian validitas menggunakan validitas konstruk dengan melakukan analisis faktor konfirmatori (confirmatory factor analysis). Analisis
a) Penolakan implementasi aturan liberal,
b) Implementasi hukum berbasis agama
c) Pandangan terhadap sistem pemerintahan sekarang.
a) Pemenuhan hak bagi pemeluk agama lain
b) Hubungan interpersonal dengan pemeluk agama lain.
a) Pandangan bahwa Syi'ah dapat memicu kemarahan umat Islam

b) Larangan terhadap Syi'ah karena telah melanggar prinsip-prinsip dalam Islam

c) Pandangan bahwa keberadaan Syi'ah dapat membahayakan umat pada aliran Islam lainnya.

a) Menolak dakwah melalui internet

b) Menolak penggunaan konten Islam dalam entertainment atau pertelevisian.

a) Sikap terhadap keterlibatan perempuan di ruang publik

b) Persepsi mengenai hak-hak perempuan di ruang publik.

dilakukan dengan dua tahap yaitu tahap pertama menguji validitas dari setiap aitem dari setiap dimensi dan tahap kedua menguji validitas dari setiap dimensi dari konstruk konservatisme dalam Islam.

Confirmatory Factor Analysis (CFA) sebagai bagian dari pengujian model pengukuran dalam Structural Equation Modeling (SEM) dilakukan dengan bantuan Lavaan Package ver 0,5-22 (Rosseel, 2012), yang tersedia pada program $R$ versi 3.6.2 (R Core Team, 2017). Keseluruhan analisis diukur dengan maximum likelihood estimation serta menggunakan robust standard error dan Satorra-Bentler Scaled Chi-square sebagai metode untuk mengoreksi model statistik (Rosseel, 2012). Indeks "fit" (kesesuaian model teoritis dengan data di lapangan) yang digunakan sebagai kriteria penentu adalah: Comparative Fit Indices (CFI) >0,93; Root Mean Square Error of Approximation (RMSEA) $<0,08$ 
dan Standardized Root Mean Square Residual (SRMR) $<0,08$ (Hair, Black, Babin, \& Anderson, 2019). Keseluruhan analisis dilakukan dengan bantuan program $\mathrm{R}$ versi 3.6.2 (R Core Team, 2017).

Analisis aitem juga dilakukan untuk menentukan daya diskriminasi masingmasing aitem dengan melihat nilai koefisien korelasi aitem dengan skor total aitem (rit), muatan faktor dan proportion of endorse-ment (PoE). Ketiga kriteria ini dijadikan dasar untuk menyeleksi aitem.

Tabel 2. Kriteria Seleksi Aitem

\begin{tabular}{ll}
\hline \multicolumn{1}{c}{ Kriteria } & \multicolumn{1}{c}{$\begin{array}{c}\text { Standar aitem lolos } \\
\text { seleksi }\end{array}$} \\
\hline Koefisien korelasi & 0,3 (Dancey \& Reidy, \\
antara aitem & 2007) \\
dengan skor total & 0,4 (Comrey \& Lee, \\
Muatan faktor & $\begin{array}{l}1992) \\
\text { PoE }\end{array}$ \\
\hline
\end{tabular}

\section{Studi 2}

Studi 2 dilakukan untuk menguji validitas konvergen alat ukur Konservatisme Islam sehingga memperkuat validitas alat ukur dan memastikan kembali alat ukur baik untuk digunakan. Validitas konvergen diuji dengan mengkorelasikan alat ukur Konservatisme Islam dengan skala Right Wing Authoritarianism (RWA) yang telah diadaptasi ke dalam bahasa Indonesia oleh Laboratorium Psikologi Politik Universitas Iindonesia(unpublished). RWA merupakan skala unidimensional yang mengukur perbedaan individu dalam hal otoritarianisme yaitu individu yang secara sosial lebih konservatif, intoleran, lebih memilih peraturan dan hukum yang ketat dan mendukung kontrol sosial yang keras, otoriter dan punitif (Bizumic \& Duckitt, 2018). Skala ini dipilih karena konservatisme sendiri merupakan salah satu aspek dalam RWA, sehingga diindikasikan ke-duanya akan berkorelasi positif (Duckitt \& Bizumic, 2013). Lebih lanjut, penelitian-penelitian sebelumnya telah menemukan RWA mem- prediksi konservatisme dalam hubungan agama, sosial, ekonomi dan politik serta penolakan terhadap kebijakan-kebijakan yang liberal (Altemeyer \& Hunsberger, 1992; Jost, Glaser, Kruglanski, \& Sulloway, 2003; Mcadams, Hanek, \& Dadabo, 2013).

Tidak hanya berhubungan dengan pandangan konservatisme dalam agama Katolik, penelitian Ji dan Ibrahim (2007) menemukan adanya korelasi positif antara RWA dengan pandangan religius Islam pada masyarakat muslim di Indonesia. Oleh karena itu, penulis mengasumsikan tingkat konservatisme Islam akan berkorelasi positif dengan tingkat RWA seseorang, dengan kata lain semakin tinggi skor konservatisme Islam individu, semakin tinggi pula skor RWA-nya.

Skala RWA terdiri dari 6 aitem dengan nilai Cronbach Alpha sebesar 0,75. Contoh aitemnya adalah sebagai berikut: "Nilai dan cara-cara tradisional hingga saat ini masih merupakan cara yang terbaik untuk dijadikan pedoman dalam hidup"; "Penting bagi anak-anak untuk belajar patuh pada otoritas, baik orang tua, guru maupun pemimpin di masyarakat". Dalam studi 2, kedua skala Konservatisme Islam dan RWA dibagikan ke 203 responden. Sejumlah $62.5 \%$ responden merupakan perempuan dan beragama Islam. Rerata usia responden 25.24 tahun. Adapun penjelasan singkat mengenai status sosioekonomi responden adalah sebagai berikut: responden memiliki tingkat pendidikan yang cukup tinggi dengan $62.8 \%$ responden telah menyelesaikan S1, $24.9 \%$ responden telah menyelesaikan SMA, dan $22.5 \%$ merupakan mahasiswa S1.

\section{Hasil}

\section{Studi 1}

Berdasarkan hasil pengujian reliabilitas terhadap masing-masing dimensi didapatkan koefisien Cronbach Alpha sebesar 0,770 hingga 0,951 . Selain itu, hasil peng- 
ujian reliabilitas terhadap keseluruhan alat ukur menghasilkan koefisien Cronbach Alpha sebesar 0,921. Hal ini mengindikasikan alat ukur memiliki reliabilitas yang baik, dalam arti alat ukur memiliki aitemaitem yang homogen dan secara konsisten mengukur satu konstruk yang sama. Berdasarkan hasil pengujian validitas menggunakan confirmatory factor analysis (CFA) terhadap model pengukuran dari alat ukur konservatisme religius dalam Islam yang terdiri dari 5 (lima) dimensi dan 61 aitem, diperoleh $\quad \chi 2(1764)=3835,814 ; \quad \mathrm{p}<0.05$; $\mathrm{CFI}=0,688$; SRMR $=0,157$; RMSEA $=0,076$ yang menunjukkan bahwa model dari alat ukur konservatisme religius dalam Islam denga 5 dimensi tidak fit, dalam arti data tidak sesuai dengan model, karena tidak memenuhi satupun indeks baik CFI, SRMR maupun RMSEA. Hasil analisis aitem kemudian dijadikan patokan untuk menyeleksi aitem-aitem yang baik.
Konservatisme dalam Islam dengan 3
Dimensi

Setelah menganalisis aitem-aitem dari tiap dimensi, peneliti memutuskan untuk mengeliminasi 2 (dua) dimensi yang memiliki sejumlah aitem yang kurang baik dan secara aspek tidak cukup baik menggambarkan konservatisme Islam Indonesia. Kedua dimensi tersebut adalah dimensi hubungan dengan bukan muslim (hub) dan dimensi hubungan Islam dan media (med). Melalui seleksi yang ketat, kami memutuskan untuk menghapus dimensi hubungan dengan bukan muslim karena keseluruhan aitem cenderung memiliki tingkat social desirability yang tinggi.

Sementara dimensi kedua yang kami eliminasi adalah dimensi Islam dan media. Dimensi ini sulit untuk digunakan dalam membedakan tingkat konservatisme Islam seseorang. Hal ini dikarenakan pada masa perkembangan teknologi seperti saat ini,

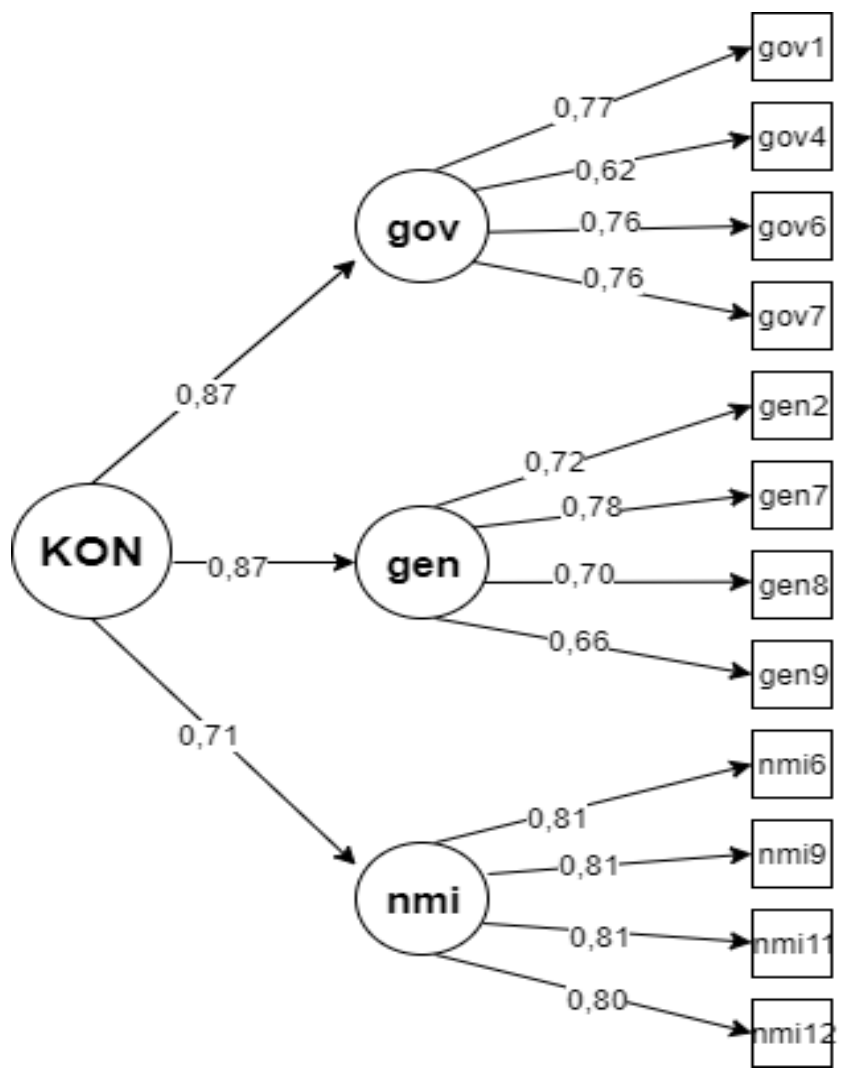

Keterangan:

KON = Konservatisme Islam gov = dimensi pemerintahan dalam Islam gen $=$ dimensi isu gender nmi = dimensi non-mainstream Islam

Gambar 1. Hasil CFA Konservatisme Islam 3 Dimensi 
semua orang, baik yang konservatif maupun tidak, telah menggunakan media sebagai penyebaran doktrin agama. Karena itu, diputuskan untuk mengeliminasi dimensi tersebut. Lebih lanjut, pemilihan 3 (tiga) dimensi saja dari alat ukur ini telah cukup menggambarkan konservatisme Islam.

Dari proses analisis aitem juga ditemukan hanya 3 (tiga) dimensi yang memiliki aitem-aitem yang memenuhi kriteria aitem yang baik. Dimensi-dimensi tersebut adalah sikap terhadap pemerintahan, sikap terhadap non-mainstream Islam dan sikap terhadap isu gender. Secara keseluruhan, model pengukuran dari alat ukur konservatisme dalam Islam dengan 3 (tiga) dimensi dapat dikatakan fit karena telah memenuhi tiga kriteria cut-off dengan nilai $\mathrm{CFI}=0,959$, nilai $\mathrm{SRMR}=0,051$ dan nilai RMSEA $=0,06$. Ketiganya juga memiliki reliabilitas yang baik, dilihat dari nilai koefisien Cronbach Alpha tiap dimensi antara 0,813-0,893. Hasil pengujian model CFA dan muatan faktor masing-masing dimensi dan masing-masing aitem ditunjukkan pada Gambar 1. Seluruh muatan faktor berada pada kisaran angka di atas 0,5 yaitu pada rentang $0,66-0,87$. Nilai ini menunjukkan masing-masing aitem dan dimensi telah cukup baik menjelaskan model pengukuran (Hair et al., 2019).

\section{Studi 2}

Pengujian validitas alat ukur konservatisme Islam menggunakan confirmatory factor analysis (CFA) untuk menguji validitas konstruk dan korelasi dengan skala RWA untuk menguji validitas kon-vergen. CFA dilakukan dengan Structural Equation Modeling (SEM) menggunakan package lavaan ver. 0.6-5 pada program $\mathrm{R}$ versi 3.6.2. Indeks fit yang digunakan sebagai kriteria penentu sama dengan studi sebelumnya yaitu CFI $>0,93$; RMSEA $<0,08$ dan SRMR < 0,08 (Hair et al., 2019). Sebelum dilakukan uji validitas, dilakukan uji normalitas untuk menentukan estimasi yang digunakan untuk uji CFA. Hasil uji norma- litas menunjukkan bahwa data normal ( $\mathrm{p}=0.09)$ sehingga estimasi yang digunakan adalah MLM (Maximum Likelihood Model).

Hasil CFA menunjukkan alat ukur konservatisme 3 dimensi memiliki nilai $\mathrm{CFI}=0,940$, RMSEA $=0,78$ dan SRMR $=$ 0,06 yang mengindikasikan model alat ukur fit karena telah memenuhi 3 kriteria yang telah ditetapkan. Selain memiliki validitas konstruk yang bagus, alat ukur konservatisme Islam ini juga memiliki validitas konvergen yang baik sesuai dengan hasil korelasi dengan skala RWA signifikan dan positif ( $\mathrm{p}<0,05 ; \mathrm{r}=0,154)$.

\section{Pembahasan}

Pada studi 1, dilakukan penyusunan alat ukur konservatisme religius dalam Islam yang dikembangkan berdasarkan hasil penelitian Zuhdi (2018). Tahapan yang dilakukan adalah uji reliabilitas alat ukur per dimensi dan secara keseluruhan, lalu dilanjutkan uji validitas. Berdasarkan hasil pengujian, dapat ditemukan bahwa konservatisme religius dalam Islam dapat diukur melalui pengukuran terhadap 3 (tiga) dimensi yaitu sikap terhadap pemerintahan, sikap terhadap Islam non-mainstream, dan sikap terhadap isu gender.

Dimensi sikap terhadap pemerintah berkaitan dengan implementasi hukum Islam dalam pemerintahan. Pemilihan dimensi ini sejalan dengan hasil penelitianpenelitian konservatisme Islam yang merujuk pada pandangan terhadap implementasi hukum sebagai salah satu aspek pembeda antara konservatisme Islam tinggi dan rendah (Fossati, 2019; Mietzner \& Muhtadi, 2019).

Dimensi kedua, yaitu sikap terhadap Islam non-mainstream menjelaskan aspek penerimaan terhadap aliran Islam Syiah yang bersifat non-mainstream dan dianggap menyimpang dari ajaran konvensional Islam. Kelompok ini juga menjadi sasaran pelanggaran kebebasan beragama (Sebastian \& Arifianto, 2020). Dimensi 
ketiga adalah permasalahan gender. Pandangan terhadap peran perempuan khususnya menjadi pemisah antara pandangan konservatif dengan liberal (Brenner, 2011). Salah satu perdebatan antara lain masalah apakah perempuan bisa menjadi pemimpin serta pembelaan hak-hak perempuan yang sering dianggap kebarat-baratan dan tidak sesuai dengan tradisi Islam (Wieinga, 2009).

Kedua dimensi lainnya yaitu sikap terhadap hubungan antara muslim dan bukan muslim (nonmuslim) serta sikap terhadap Islam dan media tidak valid untuk digunakan dalam mengukur konservatisme Islam. Pada dimensi sikap terhadap hubungan muslim dan bukan muslim, sebagian besar aitem tidak memenuhi kriteria aitem yang baik, dengan muatan faktor yang rendah serta nilai PoE yang mengindikasikan social desirability yang tinggi. Hal ini bisa di-karenakan pengukuran sikap terhadap out-group dan toleransi terhadap keberagaman cenderung menimbulkan social desirability yang tinggi. Adanya konsep ketakutan akan terlihat memiliki prasangka membuat sulit untuk menentukan apakah pengukuran self-report benar menggambarkan adanya toleransi atau menutupi sikap mereka untuk menghindari kritik (Brown-Iannuzzi, Najle, \& Gervais, 2019).

Meski demikian, dimensi hubungan dengan nonmuslim penting untuk dimasukkan. Berdasarkan hasil wawancara kepada seorang ilmuwan Islam, dimensi hubungan muslim dengan nonmuslim dapat menggambarkan dinamika interaksi pada orangorang konservatif, sehingga dimensi tersebut tidak dapat diabaikan. Kami menganjurkan adanya perbaikan dalam dimensi ini dalam pengembangan alat ukur selanjutnya atau dengan mengembangkan suatu pengukuran yang bersifat tidak langsung (Brown-Iannuzzi et al., 2019).

Pada dimensi Islam dan media, konsep yang dikembangkan oleh peneliti dalam dimensi ini yang berfokus pada penghindaran penggunaan media dalam menyebarkan ajaran Islam tidak sesuai dengan konteks saat ini. Setelah dilakukan wawancara kepada seorang pemuka agama, diperoleh penjelasan bahwa media tidak lagi relevan untuk menentukan konservatisme Islam seseorang. Sebab, saat ini baik individu yang memiliki orang konservatif maupun tidak akan sama-sama menggunakan media untuk menyebarkan ajaran Islam (Arifin, 2019). Bahkan, dakwah melalui media sosial, saat ini dianggap lebih efektif daripada dakwah dengan bertatap muka karena bisa menjangkau umat Islam lebih banyak lagi tanpa memerlukan biaya yang lebih (Purwanto, Taufik, \& Jatnika, 2017). Misalnya pada beberapa kelompok radikal, media justru digunakan untuk memfasilitasi sikap intoleransi dalam beragama (Hamayotsu, 2013). Lim (2005) misalnya menemukan bahwa kelompok Laskar Jihad menggunakan internet dan media untuk menyebarkan informasi pada komunitasnya pada saat terjadinya konflik agama di Maluku untuk mendapatkan simpati publik dalam berjihad.

Pengujian alat ukur pada studi ini dilakukan melalui pengujian validitas konstruk dengan CFA dan pengujian reliabilitas dengan metode Cronbach Alpha. Secara konstruk, alat ukur konservatisme dalam Islam dengan 3 (tiga) dimensi telah terbukti valid dan reliabel. Meski demikian perlu dicatat bahwa dalam pengujiannya, alat ukur ini hanya diuji validitas dan reliabilitasnya pada responden yang didominasi oleh responden dengan pendidikan terakhir sarjana.

Studi 2 dilakukan untuk menguji validitas konstruk alat ukur Konservatisme Islam 3 dimensi yang dikembangkan dalam studi 1 serta menguji validitas konvergen alat ukur ini dengan alat ukur sejenis yaitu Right Wing Authoritarianism (RWA). Sejalan dengan hasil studi 1 , hasil studi 2 menunjukkan alat ukur Konservatisme Islam 3 dimensi memiliki model yang baik. Selain dilakukan uji validitas konstruk, dilakukan juga uji validitas konvergen. Hasil uji validitas menunjukkan alat ukur ini memiliki validitas konvergen yang baik 
karena hasilnya positif dan signifikan mengukur satu konsep yang serupa, sejalan dengan penelitian dan teori-teori sebelumnya mengenai RWA dan konservatisme (contoh: Altemeyer \& Hunsberger, 1992; Duckitt \& Bizumic, 2013; Jost et al., 2018; Mcadams et al., 2013).

Dalam kaitan konservatisme Islam dengan RWA, Ji dan Ibrahim (2007) berargumen bahwa keyakinan kuat terhadap tradisi dalam ajaran Islam terdahulu serta memandang ajaran ini sebagai suatu yang suci dan tidak bisa diubah mempengaruhi muslim konservatif menjadi taat pada norma-norma konvensional yang absolut. Hal ini kemudian memicu mereka untuk mendukung kuat tradisi yang sudah ada dan penolakan kuat terhadap mereka yang tidak konformis atau orang-orang yang dianggap liberal dan muslim yang nonmainstream.

\section{Simpulan}

Kami melakukan 2 studi untuk mengembangkan alat ukur konservatisme religius dalam Islam. Berdasarkan studi 1, yang menguji alat ukur Konservatisme Islam, diputuskan untuk melakukan perbaikan alat ukur dengan pengurangan beberapa aitem dan 2 dimensi yang tidak baik secara psikometrik sehingga dihasilkan alat ukur Konservatisme Islam dengan 3 (tiga) dimensi. Alat ukur ini kemudian diujikan sekali lagi dalam studi 2 untuk melihat validitas konstruk dan konvergen. Secara keseluruhan dapat disimpulkan bahwa alat ukur Konservatisme Islam 3 dimensi ini reliabel, valid, dan memiliki aitem-aitem yang baik. Alat ukur konservatisme religius dalam Islam dalam bentuk final memiliki 3 (tiga) dimensi yaitu sikap terhadap pemerintah, sikap terhadap Islam nonmainstream, dan sikap terhadap isu gender dapat dikatakan reliabel dan valid secara konstruk. Aitem-aitem dari ketiga dimensi tersebut yang termuat dalam alat ukur ini memiliki konsistensi antar aitem dan nilai muatan faktor. Sebagai tambahan, aitemaitem yang dipilih adalah aitem yang memiliki tingkat social desirability yang rendah. Dua dimensi lain yaitu sikap terhadap hubungan muslim dan bukan muslim serta sikap terhadap Islam dan media dalam pengujian kali ini ditemukan tidak valid dalam mengukur konservatisme religius dalam Islam.

Sejalan dengan hasil analisis validitas konstruk studi 1, alat ukur Konservatisme Islam 3 dimensi memenuhi kriteria indeks fit yang baik. Selain itu, alat ukur ini memiliki validitas konvergen yang bagus karena berkorelasi positif dan signifikan dengan konstruk terkait.

\section{Saran}

Dalam pengembangan alat ukur Konservatisme Islam yang kami lakukan, terdapat dua dimensi yang harus dieliminasi dari 5 pilihan dimensi awal yaitu dimensi hubungan dengan pemeluk agama lain dan Islam dengan media. Pada dimensi hubungan dengan pemeluk agama lain, keseluruhan aitem memiliki tingkat social desirability yang tinggi. Oleh karena itu, kami menganjurkan penelitian selanjutnya atau pengembangan alat ukur selanjutnya bisa meminimalisir social desirability ini dengan menyusun aitem-aitem yang lebih baik. Selain itu, hubungan Islam dengan media juga harus dieliminasi karena aspek ini bisa ditafsirkan ke dalam berbagai konteks, apakah dimaksudkan tentang bagaimana Islam digambarkan di media atau penggunaan media sebagai modalitas penyebaran dakwah. Hal ini dikarenakan keduanya bisa jadi menghasilkan sikap yang berbeda dalam kaitannya dengan Konservatisme Islam. Penelitian selanjutnya dapat berfokus dalam mengkaji topik ini. 


\section{Daftar Pustaka}

Altemeyer, B., \& Hunsberger, B. (1992). Authoritarianism, religious fundamentalism, quest, and prejudice. The International Journal for the Psychology of Religion, 2(2), 113133.

https://doi.org/10.1207/s15327582ijpr $0202 \_5$

Arifianto, A. R. (2019). What the 2019 election says about Indonesian democracy. Asia Policy, 14(4), 4653.

https://doi.org/10.1353/asp.2019.0045

Arifin, F. (2019). Mubalig Youtube Dan Komodifikasi Konten Dakwah. AlBalagh: Jurnal Dakwah Dan Komunikasi, 4(1), 91. https://doi.org/10.22515/balagh.v4i1. 1718

Assyaukanie, L. (2017). Unholy Alliance: Ultra-Conservatism and Political Pragmatism in Indonesia. Asean Studies Program, 19. Retrieved from https://thcasean.org/read/articles/327/ Unholy-Alliance-Ultra-Conservatismand-Political-Pragmatism-inIndonesia

Assyaukanie, L. (2018). Akar-Akar Legal Intoleransi dan Diskriminasi di Indonesia. MAARIF Journal, 13(2), 27-42. Retrieved from http://www.jurnal-

maarifinstitute.org/index.php/maarif/a rticle/view/20

BBCNews, I. (2019). Larangan rayakan Natal bersama di Dharmasraya: "Kami patuh, tapi hati kami menangis." BBC.Com/Indonesia. Retrieved from https://www.bbc.com/indonesia/5086 4097

Bizumic, B., \& Duckitt, J. (2018). Investigating right wing authoritarianism with a very short authoritarianism scale. Journal of Social and Political Psychology, 6(1), 129-150.

https://doi.org/10.5964/JSPP.V6I1.83 5

Brenner, S. (2011). Private moralities in the public sphere: Democratization, Islam, and gender in Indonesia. American Anthropologist, 113(3), 478-490. https://doi.org/10.1111/j.15481433.2010.01355.x

Brown-Iannuzzi, J. L., Najle, M. B., \& Gervais, W. M. (2019). The Illusion of Political Tolerance: Social Desirability and Self-Reported Voting Preferences. Social Psychological and Personality Science, 10(3), 364-373. https://doi.org/10.1177/19485506187 60147

Comrey, A. L., \& Lee, H. B. (1992). Interpretation and application of factor analytic results. In A. L. Comrey, \& H. B. Lee (Eds.), A First Course in Factor Analysis (p. 2). Hillsdale, NJ: Lawrence Eribaum Associates.

Dancey, C. P., \& Reidy, J. (2007). Statistics without maths for psychology. Pearson Education.

Duckitt, J., \& Bizumic, B. (2013). Multidimensionality of Right-Wing Authoritarian Attitudes: Authoritarianism-ConservatismTraditionalism. Political Psychology, 34(6), 841-862. https://doi.org/10.1111/pops.12022

Fossati, D. (2019). The Resurgence of Ideology in Indonesia: Political Islam, Aliran and Political Behaviour. Journal of Current Southeast Asian Affairs, 38(2), 119-148. https://doi.org/10.1177/18681034198 68400 
Hair, J. F., Black, W. C., Babin, B. J., \& Anderson, R. E. (2019). Multivariate Data Analysis (8th ed.). Cengage.

Hamayotsu, K. (2013). The Limits of Civil Society in Democratic Indonesia: Media Freedom and Religious Intolerance. Journal of Contemporary Asia, 43(4), 658-677. https://doi.org/10.1080/00472336.201 3.780471

Hamayotsu, K. (2018). Moderate-radical Coalition in the Name of Islam: Conservative Islamism in Indonesia and Malaysia. Kyoto Review of Southeast Asia, 23. https://kyotoreview.org/issue23/conservative-islamism-indonesiamalaysia/

Ji, C. H., \& Ibrahim, Y. (2007). Islamic religiosity in right-wing authoritarian personality: The case of Indonesian Muslims. Review of Religious Research, 49(2), 128-146. https://www.jstor.org/stable/2044748 5

Jost, J. T., Glaser, J., Kruglanski, A. W., \& Sulloway, F. J. (2003). Political conservatism as motivated social cognition. Psychological Bulletin, 129(3), 339. https://doi.org/10.4324/97813151758 67

Kruglanski, A. W. (2018). The motivated mind: The selected works of Arie W. Kruglanski. The Motivated Mind: The Selected Works of Arie Kruglanski, 129(3), $1-377$. https://doi.org/10.4324/97813151758 67

Lestari, K. R. (2017). Attacks on religious freedom in Indonesia increasing. UCANews.Com. Retrieved from https://www.ucanews.com/news/attac ks-on-religious-freedom-in-indonesiaincreasing/78242

Lim, M. (2005). Islamic Radicalism and
Anti Americanism in Indonesia: The Role of the Internet. Islamic Radicalism and Anti-Americanism in Indonesia: The Role of the Internet. Washington: East-West Center.

Mcadams, D. P., Hanek, K. J., \& Dadabo, J. G. (2013). Themes of selfregulation and self-exploration in the life stories of religious american conservatives and liberals. Political Psychology, 34(2), 201-219. https://doi.org/10.1111/j.1467-

9221.2012.00933.x

Mietzner, M., \& Muhtadi, B. (2018). Explaining the 2016 Islamist Mobilisation in Indonesia: Religious Intolerance, Militant Groups and the Politics of Accommodation. Asian Studies Review, 42(3), 479-497. https://doi.org/10.1080/10357823.201 8.1473335

Mietzner, M., \& Muhtadi, B. (2019). 9. The mobilisation of intolerance and its trajectories: Indonesian Muslims' views of religious minorities and ethnic Chinese. Contentious Belonging, 155-174. https://doi.org/10.1355/97898148434 78-013

Odahl-Ruan, C. A., Todd, N. R., \& Wilson, M. (2017). "Because the Bible tells me so": Religious conservatism and gender role attitudes in Christian campus-ministry groups at public universities. Australian Community Psychologist, 28(2).

https://doi.org/10.13140/RG.2.1.4015. 4085

Oller, J. W. (1981). Research on the Measurement of Affective Variables: Some Remaining Questions. New Dimensions in Second Language Acquisition Research, 106, 14-28. https://doi.org/10.13140/RG.2.1.4015. 4085 
Purwanto, Y., Taufik, M., \& Jatnika, A. W. (2017). Peran Teknologi Informasi Dalam Perkembangan Dakwah Mahasiswa. Jurnal Sosioteknologi, 16(1), 94-109. https://doi.org/10.5614/sostek.itbj.201 7.16.1.8

R Core Team. (2017). R: A Language and Environment for Statistical Computing. Vienna, Austria. Retrieved from https://www.rproject.org/

Rosseel, Y. (2012). \{lavaan\}: An $\{R\}$ Package for Structural Equation Modeling. Journal of Statistical Software, 48(2), 1-36. Retrieved from http://www.jstatsoft.org/v48/i02/

Sebastian, L. C., \& Arifianto, A. R. (2020). TRaNS special section on Growing Religious Intolerance in Indonesia. TRaNS: Trans-Regional and National Studies of Southeast Asia, $8(1)$ 1-5. https://doi.org/10.1017/trn.2020.1

Setijadi, C. (2017). Chinese Indonesians in the Eyes of the Pribumi Public. ISEAS - Yusof Ishak Institute, (73), 1-12. Retrieved from https://www.iseas.edu.sg/images/pdf/I SEAS_Perspective_2017_38.pdf

Terrizzi, J. A., Shook, N. J., \& Larry Ventis, W. (2012). Religious conservatism: An evolutionarily evoked disease-avoidance strategy.
Religion, Brain and Behavior, 2(2), 105-120.

https://doi.org/10.1080/2153599X.20 12.695514

Van Bruinessen, M. (2014). Mukadimah: Perkembangan Kontemporer Islam Indonesia dan 'Conservative Turn'. Dalam M. van Bruinessen (ed.). Conservative Turn: Islam Indonesia dalam Ancaman Fundamentalisme (pp. 1-18). Mizan.

Van Bruinessen, M. (2011). What happened to the smiling face of Indonesian Islam? Muslim intellectualism and the conservative turn in post-Suharto Indonesia. RSIS Working Paper No. 222, (January), 1$45 . \quad$ Retrieved from https://www.files.ethz.ch/isn/127995/ WP222.pdf

Weima, J. (1965). Authoritarianism, Religious Conservatism, and Sociocentric Attitudes in Roman Catholic Groups. Human Relations, 18(3), 231-239. https://doi.org/10.1177/00187267650 1800303

Wieinga, S. E. (2009). Women resisting creeping Islamic fundamentalism in Indonesia. Asian Journal of Women's Studies, 15(4), 30-56. https://doi.org/10.1080/12259276.200 9.11666077 